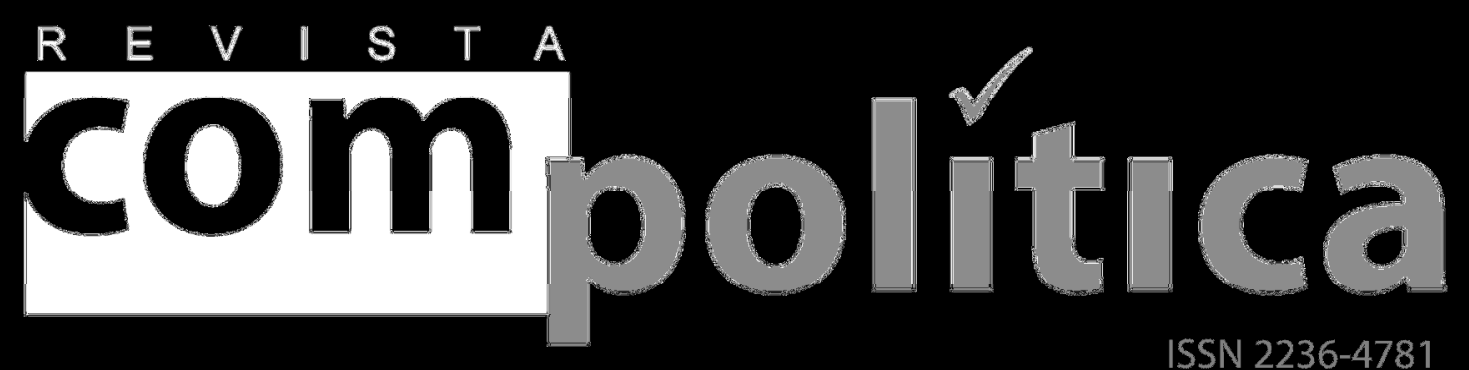

ISSN 2236-4781

\title{
SANGIRARDI, Pedro
}

Mestre em Comunicação e Cultura pela UFRJ.

[A publicação do material abaixo, ainda inédito, foi autorizada pela família de Pedro Sangirardi, a pedido da Revista Compolítica, na qual o autor trabalhou como revisor. Sangirardi foi ainda doutorando do Programa de Pós-Graduação em Comunicação da Verj. O artigo "Tecnologias cognitivas, comunicação e a crise de representação política" foi revisado por Fátima Régis de Oliveira e Fernanda Sanglard.]

\section{Tecnologias cognitivas, comunicação e a crise de representação política}

\section{RESUMO}

O artigo tematiza as tensões decorrentes da adequação da estrutura hierárquica e verticalizada da representação política ao ambiente das redes distribuídas de comunicação. Analisa como propriedades das tecnologias digitais vêm desestabilizando os sistemas de intermediação política, tradicionalmente estruturados segundo a lógica da comunicação de massa. As assimetrias entre os meios massivos e a internet são o campo de exploração dos modos como os dispositivos das tecnologias da informação e comunicação (TIC) transformam os padrões cognitivos no processamento da enorme variedade de informação política na web. O objetivo é compreender a influência da transição tecnológica comunicacional no fenômeno de personalização midiática da política.

Palavras-chaves: TIC; cognição; representação política.

\section{ABSTRACT}

The article thematizes the tensions arising from the suitability of hierarchical and vertical structure of political representation to the environment of distributed communication networks. Analyze how properties of digital technologies have destabilizing political mediation systems traditionally structured according to the mass media logic. The asymmetries between the mass media and the internet are the field of exploration of the ways information and communication technologies (ICT) devices transform the cognitive patterns in processing huge variety of political information on the web. The goal is to understand the influence of communication technology transition in the phenomenon of media personalization of politics.

Keywords: information and communication technologies (ICT); cognition; political representation. 


\section{Tecnologias cognitivas, comunicação e a crise de representação política}

\section{[Cognitive technologies, communication and the crisis of political representation]}

SANGIRARDI, Pedro

$\mathrm{N}$ a esteira de acontecimentos afins ocorridos em diversas partes do mundo, as mobilizações de junho de 2013 no Brasil evidenciaram a descrença com os mecanismos tradicionais de mediação política e a degeneração do sentimento de pertença democrática dos cidadãos. Ainda que desprovidas de um objetivo claro, as múltiplas e difusas reivindicações destacaram a defasagem de bandeiras partidárias na representação dos interesses dos brasileiros. Por outro lado, as manifestações e seus desdobramentos demonstraram a força do potencial mobilizador das tecnologias com destaque para os dispositivos de conexão móvel -, renovando a importância da atenção à disputa em torno da regulação de usos e apropriações destas ferramentas. Os eventos de junho sacudiram a certeza do rumo para a despolitização total, em que a política profissional, exercendo com crescente autonomia as prerrogativas do poder público, deixaria a participação popular restrita ao voto em candidatos pré-selecionados em períodos pré-determinados.

Dois aspectos relativos a estes acontecimentos serão problematizados neste trabalho. O primeiro é o descontentamento com o modelo de representação política, que será pensado em consonância com o segundo, o potencial das tecnologias da informação e comunicação (TIC) em criar condições para a inovação nas formas de relacionamento entre representantes e representados.

Pertencendo esta pesquisa ao campo da comunicação, seu enfoque está menos nas questões técnicas e legais concernentes à relação entre política e tecnologia do que na base discursiva, cultural e cognitiva que se estrutura em acoplagem às redes distribuídas de comunicação digital. O objetivo é contribuir com o debate sobre a crise da representação política nas sociedades contemporâneas, à luz 
da influência das TIC nas formas e padrões de sociabilidade e relacionamento. Intenta-se explorar como a comunicação política, forjada no modelo top down das mídias de massa, pode ser transformada em ambientes organizados por estruturas cognitivas emergentes.

Nosso interesse está na possibilidade de gramáticas específicas aos ambientes de comunicação em rede, ao longo do tempo, desenvolverem um padrão cognitivo mais proativo, que se distinga qualitativamente da "passividade" do receptor frente ao espetáculo político midiático que marca a idade de ouro da comunicação de massa. Cumpre-nos refletir sobre as condições para a constituição de ambientes onde a transparência, a prestação de contas e o aumento da influência popular na tomada de decisão política. De que forma elas podem ser uma alternativa à lógica calcada em eventos e personalidades, que opera na indiscernibilidade entre os terrenos da informação e do entretenimento?

\section{O valor da comunicação no capitalismo cognitivo}

O capitalismo cognitivo deveria talvez ser definido como exploração da nossa potência de abstração, compreendida como poder cognitivo do nosso organismo, força viva que inventa quotidianamente novas normas e práticas, força viva que nos serve para projetar a nossa mísera identidade além de nós mesmos, força viva que é capaz de construir empatia e comum, e que obviamente é capaz de manipular mercadorias, instrumentos, máquinas e informações (Pasquinelli, 2013).

A crise de representatividade política se insere no contexto mais amplo de uma crise do próprio capitalismo. Mais do que uma crise econômica, é uma crise da economia e de sua medida, processo em que a comunicação tem papel destacado, como demonstraremos principalmente com o apoio do trabalho do filósofo e economista Yann Moulier Boutang (2012). o ponto de partida é a financeirização do capital, que desloca as formas de acumulação capitalista para a captura de um tipo de valor imaterial e simbólico, presente no que o autor classifica de externalidade:

Lembremos que uma externalidade aparece assim que uma transação, seja ela comercial ou não (daí sua dimensão simbólica e não monetária), tenha como consequência produzir um efeito positivo (aumento do benefício) ou negativo sobre um terceiro (Boutang,2012, p. 75). 
No exemplo de Hardt \& Negri para o conceito de externalidade, ela ocorre "quando meu vizinho embeleza sua casa e seu jardim e o valor da minha propriedade também aumenta".

\begin{abstract}
De maneira mais geral e fundamental, as externalidades positivas designam riqueza social criada fora do processo produtivo direto, cujo valor só em parte pode ser apreendido pelo capital. Os conhecimentos, relações e formas de comunicação resultantes da produção imaterial geralmente se enquadram nesta categoria (Hardt \& Negri, 2005, p. 196).
\end{abstract}

As externalidades são cada vez mais importantes no sistema produtivo imaterial, este que é decorrente do atravessamento de uma economia da troca por uma economia da colaboração. 0 capital não paga pelas fontes externas de riqueza que não cessa de capturar, reelaborar e embutir em seus produtos e serviços, antes de pô-los novamente em circulação com um valor cultural renovado. Mas o capitalismo também não é capaz de controlar as externalidades como gostaria, e elas mesmas podem ser lócus da resistência às suas investidas.

Para nosso propósito, basta-nos a ideia de externalidade como aquilo da ordem do não quantificável, da dimensão do afeto; produção subjetiva, resultante dos procedimentos de subjetivação e das explorações sensoriais dos corpos em suas interações e atividades; trata-se de um além-da-medida: "uma produção que contém outras medidas (e modos) de experimentar a própria vida e que extravasa o padrão da relação capitalista e do valor de troca" (Mendes, 2012, p. 276). A oposição esquemática entre a economia tradicional e a "economia das externalidades" aqui nos será útil para uma compreensão da finança contemporânea em sua relação intrínseca com a comunicação. Boutang demonstra com sua metáfora da polinização, sintetizada a seguir, a importância das externalidades.

De acordo com a economia política tradicional, o que as abelhas fazem é produzir mel e cera, o output obtido pelo apicultor; elas valem pela produção dessas mercadorias. Perspectivas científicas que se debruçaram mais profundamente no estudo das abelhas, entretanto, apresentam uma visão bastante diversa do valor econômico de sua atividade. 
O enorme e indispensável trabalho realizado é a polinização das plantas (80\% das frutas e legumes de que se alimentam os seres humanos). As abelhas permitem desta maneira a reprodução das plantas (ou seja, da flora) e, consequentemente, da fauna, onde os seres humanos estão no topo da cadeia. Elas possibilitam a vida da biosfera, sem a qual a vida sobre a terra seria impossível. Sua atividade essencial só pode ser apreendida como um outcome ou resultado global sistêmico (Boutang, 2012, p. 75-76).

Em referência à fábula de La Fontaine, o autor afirma que a economia tradicional só reconhece a situação binária da formiga que trabalha e poupa em oposição à da cigarra que consome. Mas a economia que leva em conta a polinização entende que "o consumo é produtivo e a circulação é diretamente produtiva" e supera essa oposição (id. ibid., p. 76). A cigarra pode produzir novas linguagens e formas de vida em seu parasitismo, que, por sua vez, são passíveis de adquirir valor de uso nas redes.

A estimativa do valor econômico da polinização, segundo Boutang, é de mil a cinco mil vezes o valor da atividade das abelhas em comparação ao cômputo da simples comercialização de mel e cera. Ele lembra que muitos apicultores nem recolhem mais o mel produzido, contentando-se em alugar o serviço de polinização que as abelhas realizam, e de uma frase atribuída a Einstein, segundo a qual "a humanidade não sobreviveria por mais de cinco anos caso as abelhas desaparecessem da face da terra" (id. ibid., p. 77-78).

Com isso, ressalta que o valor da polinização não tem preço, e que "tudo aquilo que não tem preço ou que tem um valor inestimável desafia a medida" (id. ibid., p. 78). A polinização é apresentada como exemplo de externalidade positiva, recurso invisível que agrega valor a uma mercadoria sem que a sua produção o considere. Da mesma forma que a economia tradicional conferia às externalidades papel marginal, o capitalismo enfrenta uma crise que pode estar relacionada ao mau funcionamento dos seus dispositivos de medida, que "operam na mensuração e valoração das novas formas de produção, que são, acima de tudo, produção de vida” (Mendes, 2012, p. 266).

O capitalismo cognitivo é, pois, a forma de acumulação de meios materiais e organizacionais que captura, através dos dispositivos digitais do tipo Web 2.0, uma parte das externalidades positivas resultantes da atividade de polinização da multidão humana e viva (Boutang, 2012, p. 82). 
Para o autor, tal princípio de interdependência e de interação contínua desqualifica a possibilidade de se isolar a produtividade de cada um. O efeito da polinização é necessariamente coletivo e não pode existir de outra forma. Tal metáfora, ao ser estendida para a atividade humana, encerra a ideia de que:

(...) toda forma de trabalho que produz um bem imaterial, como uma relação e um afeto, resolvendo problemas ou proporcionando informação, da criação cultural aos serviços financeiros, é fundamentalmente uma performance: sendo seu produto o próprio ato em si (Mendes, 2012, p. 272, grifo no original).

A falência dos dispositivos de medida se evidencia na tentativa de mensuração do valor agregado por uma externalidade positiva a um produto ou serviço, no desafio característico de uma sociedade da informação. O conceito de valor econômico entra em crise, pois agora um recurso significativo incorporado à produção da mercadoria é intangível. Uma medida-padrão defasada converte valores culturais e estéticos em valor monetário, na operação forçada de tangibilizar o intangível, mensurá-lo, convertê-lo a uma medida comum, reduzi-lo ao cálculo tradicional.

O ponto fundamental é sugerido por Hardt \& Negri (2005, p. 194), quando afirmam que a produção material cria os meios da vida social, enquanto a produção imaterial cria a própria vida social. A comunicação, portanto, se traduz "pela modelagem mútua de um mundo comum por meio de uma ação conjugada" (Varela apud Regis, 2011, p. 127). Concebida "não como ato individual, mas, sim, como uma instituição social” (Winkin, 1988, p. 14), a comunicação expressa sua tendência ao comum e ao compartilhado, distanciandose da perspectiva matemática inaugurada por Shannon e Weaver.

O aspecto central do paradigma da produção imaterial que precisamos apreender é a sua relação íntima com a cooperação, a colaboração e a comunicação - em suma, sua fundamentação no comum. (...) o próprio trabalho tende a produzir diretamente os meios de interação, comunicação e cooperação para a produção. O trabalho afetivo sempre constrói diretamente um relacionamento. Não só a produção de ideias, imagens e conhecimentos é conduzida em comum - ninguém realmente pensa sozinho, todo pensamento é produzido em colaboração com o pensamento passado e presente de outros - como cada nova ideia e imagem convida a novas colaborações e as inaugura (Hardt \& Negri, 2005, p. 195). 
O papel renovado da comunicação está no centro de um modelo que tem no conhecimento e na inteligência coletiva seus pilares de sustentação, com forte base nas tecnologias de informação. Mas o principal, para nosso propósito, é a reflexão sobre as implicações de um novo ambiente cognitivo nos sistemas de comunicação política.

\section{Tecnologias cognitivas e comunicação política}

Vimos como a finança de mercado contemporânea se alimenta da densa produção e circulação de subjetividade polinizada nas redes sociotécnicas. Podemos pensar nas redes sociais como plataformas "gratuitas" de polinização, onde os modos de vida que produzimos nestes espaços, geram o valor econômico que é transacionado por corporações como Google e Facebook. "Curtir", "retuitar" e recomendar um vídeo ou texto são manifestações afetivas; e as TIC vêm possibilitando que toda esta complexa teia inter-relacional de fluxos afetivos seja rastreada e medida, já que por trás de cada clique parece existir uma "unidade de afeto" a ser capitalizada. A mineração de dados realizada pelas corporações busca identificar padrões de preferências, estilos e diferenças, mapeando trajetos da ação cognitiva na rede e produzindo o valor intangível de seus produtos e serviços.

A internet está alterando a plástica cerebral de seus usuários, produzindo um rearranjo de suas habilidades cognitivas em função de objetos técnicos como tablets, telefones inteligentes e outros dispositivos de comunicação, que participam de nossa intimidade de forma nunca vista. São ferramentas que nos conectam com outras pessoas e com o mundo, desvelando um feixe ilimitado de possibilidades interativas. Por outro lado, são objetos que pertencem à esfera íntima do self, o que também faz com que em alguns momentos as pessoas prefiram o contato com seus iguais à interação com seus dispositivos.

Para a presente discussão, o que está em questão são as formas de relacionamento estimuladas pelos objetos técnicos, que não devem ser pensados somente como extensões de habilidades humanas, mas também como elementos "que reconfiguram de forma dinâmica e complexa o processo cognitivo” (Regis \& Messias, 2012, p. 42).

Esta teia de comunicação formada por pessoas, objetos técnicos, redes infraestruturais e imateriais pode estar moldando um perfil de usuário mais crítico e menos passivo, ainda que sejam numerosas as diferenças de usabilidade e conhecimento entre os usuários de internet. 


\section{Cognição, tecnologias de comunicação e representação política}

A princípio, não nos parece disparatado observar que o ambiente comunicacional da internet exige mais das habilidades técnicas e linguísticas de seus usuários do que os meios de comunicação de massa. Vejamos como essa afirmação pode ser aplicada ao estudo em curso, sobre a cognição política em sua relação com os suportes de comunicação.

Como as novas modalidades sensoriais na interface dos usuários com as materialidades dos novos meios podem afetar a cognição política? A pesquisa em comunicação política deve buscar metodologias ajustadas ao cenário de avanço das tecnologias da informação e comunicação para melhor compreender suas reverberações nos processos de formação de sentido para o universo político. A valorização de perspectivas interdisciplinares pode colaborar para dar início a esta frente de trabalho.

O modelo da probabilidade de elaboração ou Elaboration Likelihood Model - ELM (Petty \& Cacioppo, 1986) trabalha com a ideia de rotas centrais e periféricas pelas quais a persuasão pode ocorrer. 0 impacto persuasivo depende da modalidade de processamento de informação em curso no momento da exposição, podendo seguir por uma dentre as rotas. Motivação, habilidade e atenção são os elementos que precisam estar ativados para que uma pessoa pense racionalmente sobre uma mensagem e tenha envolvimento com ela, atente aos seus argumentos principais, com uma compreensão mais profunda e maior performance mental. Processos persuasivos envolvidos através da rota central de orientação cognitiva tendem a produzir efeitos mais duradouros do que os efeitos gerados pela rota periférica (Holbert et al., 2010, p. 25).

Já o processo de persuasão pela via periférica ocorre quando as pessoas estão desmotivadas, possuem pouca habilidade de processamento da informação (como em casos de barreiras idiomáticas e analfabetismo digital) ou não estão suficientemente concentradas ou dispostas a decodificar a mensagem. No curso cognitivo da rota periférica elas seriam influenciadas por fatores exteriores à mensagem, como a confiança no apresentador e a atratividade. A rota periférica é a via das elaborações sem profundidade.

Na mesma linha do modelo ELM, o modelo Opportunity, Motivation and Ability (OMA), proposto por Delli Carpini \& Keeter e Luskin (apud Prior, 2007) sugere os três componentes necessários para o aprendizado político: oportunidade, motivação e habilidade. Um dos 
princípios do modelo seria que "diferentes ambientes midiáticos proveem diferentes oportunidades de aprender sobre política" (Prior, 2007, p. 29). Seguindo sua formulação, o aparecimento das tecnologias de broadcasting diminuiu a desigualdade entre os níveis de informação política, dando à base de cidadãos acesso a conteúdo com baixa variação de qualidade e de tempo de exposição. Os meios de comunicação de massa facilitaram a recepção e diminuíram os custos cognitivos de aprendizagem política (ainda que ao preço de uma informação às vezes superficial). Contribuíram ainda para equilibrar os níveis de habilidade e indiretamente de envolvimento político, permitindo que muitas pessoas tivessem acesso à política, o que era mais difícil antes do advento dessas tecnologias.

No entanto, a comunicação de massa avançou muito pouco para aumentar a motivação dos ouvintes e telespectadores, consolidando um padrão persuasivo via rota periférica do modelo ELM. Com o aparecimento das TVs a cabo, a desigualdade de acesso volta a aumentar. A variação de conteúdo mostra-se relevante e incapaz de equalizar o nível de acesso dos diferentes estratos da população.

A internet, por sua vez, amplia as oportunidades de acesso à informação política, e consequentemente a motivação de quem queira usá-la. Mas, o acesso aos conteúdos da internet dependem do engajamento mais ativo do usuário e de suas habilidades para buscar informações. Desse modo, a internet pode contribuir com o desnivelamento das informações consumidas pelas audiências, e pode aumentar o abismo entre os níveis de educação e interesse, que influem na capacidade de selecionar informações na rede. Em suma, enquanto a televisão ajudou os menos letrados a aprenderem mais sobre a política, estivessem ou não motivados a acompanhar as notícias, o ambiente de ampla escolha da internet concentra o consumo de informação política nos usuários interessados e mais condicionados nas técnicas de filtragem e navegação.

O paralelo que se pode traçar é que na comunicação de massa, a maior parte do consumo de mensagens é processada cognitivamente pela rota periférica. $O$ contexto de poucos canais limita a exposição seletiva e aumenta a audiência inadvertida. A exposição à informação política tem baixa oportunidade (a política ocupa pouco espaço da programação) e baixa motivação (o consumo de conteúdo político ocorre, frequentemente, como subproduto de outras atividades), mas incrementa o quesito da habilidade, visto que, em relação à mídia impressa, diminuíram os custos envolvidos no consumo de informação. Já a internet favorece que o conteúdo político seja processado pela rota central, ou seja, as mensagens seriam consumidas com motivação, atenção e habilidades cognitivas necessárias.

A investigação das transformações materiais das tecnologias de comunicação ilumina a mudança nos sentidos mobilizados por elas. 
Os jornais impressos, por exemplo, convocam a visão como sentido preferencial, estabelecendo cognição baseada na cultura letrada e exigindo aptidões próprias; a televisão produz novas sensorialidades com a mobilização dos sentidos da visão e audição para interface com a mídia, recuperando a tradição oral. Os dispositivos de última geração, em suas formatações hibridizadas, introduzem a tatilidade e ampliam a experiência de multissensorialidade dos usuários.

A integração de milhões de cérebros em novos ambientes midiáticos altera os modos de produção de sentido, tornando o modelo de representação política tradicional datado. Não estamos sugerindo que seja possível prescindir das autoridades ou da função da liderança, mas apenas que o modelo de representação política vem sendo questionado ao ser abordado por um novo paradigma cognitivo, estabelecido em boa medida pela disseminação das TIC.

A Revolução Francesa, que inaugurou os preceitos democráticos sobre os quais nossa sociedade se ampara até hoje, ocorreu pouco antes de 1800, quando a população no planeta era de um bilhão de pessoas (Nepomuceno, 2013). A partir daí é que foi consolidado o Homo universalis, "em toda parte dispondo, não importa a região de origem, a classe ou a casta, do mesmo estatuto de ser e dos mesmos direitos" (Oliveira, 2003, p. 139). A Revolução representou um abalo substantivo na autoridade soberana. De lá para cá, a civilização humana se ampliou para mais de sete bilhões de pessoas, enquanto o estatuto representacional da política permaneceu essencialmente inalterado. Este salto impressionante alerta para a necessidade de inovação na governança da comunicação.

Em outras palavras, a explosão demográfica (mas não apenas ela) coloca o desafio da criação de um modelo representacional adequado às mudanças promovidas pela comunicação digital. É evidente a incapacidade dos "líderes alfa" de centralizarem a coordenação da nova escala de produção, assim como de deterem para si a responsabilidade de resposta ao volume de novos e variados problemas. Diante dos desafios postos com a necessidade de gerenciamento da nova escala de produção, nossos modelos mentais são reconfigurados, enquanto as tecnologias cognitivas criam as condições para redefinição global da governança da comunicação, que está ligada a regras e permissões de acesso, ou seja, quem diz o quê, em nome de quem, em que circunstâncias e por aí em diante, já que sistemas de moderação são mecanismos de representação e tomada de decisão.

O tipo de estruturação da inteligência colaborativa em ambiência online, com base em uma comunicação "algorítmica", é fértil para imaginar analogias com o comportamento coletivo dos insetos

\footnotetext{
${ }^{1}$ Entendidos como os grandes tomadores de decisão: gestores, executivos, juízes, parlamentares, governantes...
} 
sociais. Nosso interesse nesse tipo de inteligência é por ela se basear fundamentalmente na comunicação. Após imaginar a economia das abelhas, passamos às colônias de cupins e formigas, para chegar aos humanos, seus objetos técnicos e as cartografias progressivamente precisas de suas interações, viabilizadas pela cultura digital.

A metáfora entomológica, mais uma vez, apoia a análise de sistemas inteligentes disseminados com multiplicidade de agentes. Hardt \& Negri (2005) mencionam os cupins tropicais e suas complexas estruturas em abóbada como exemplo da inteligência de enxame, enquanto autores como Johnson (2003) e Oliveira (2003) exploram o fenômeno da emergência em colônias de formigas.

Embora a cultura popular sustente o estereótipo stalinista das formigas, como no desenho animado FormiguinhaZ, suas colônias são o oposto das economias de comando, onde não há líderes alfa e a própria ideia de uma formiga-rainha é enganadora (Johnson, 2003, p. 23-24). A formiga-rainha não exerce papel de autoridade e não comanda as outras formigas na organização do formigueiro, estrutura complexa em sua formação, onde é possível identificar um tipo de inteligência superior à soma das inteligências individuais, que surge da interação entre o conjunto e cada uma de suas partes integrantes.

As formigas, como indivíduos, agem sem objetivo definido, aleatoriamente e ao sabor dos encontros. A comunicação se dá através das trilhas de feromônios que elas secretam nas superfícies por onde passam. Quanto maior o número de formigas que se comunicam, maior a probabilidade de emergir um fenômeno imprevisível e pertencente a uma ordem superior de complexidade ${ }^{2}$.

O ponto de importância para nosso estudo é a analogia feita entre as sociedades de insetos sociais, como as formigas, e as sociedades humanas. O crescimento demográfico e a extrema divisão do trabalho aceleram o desenvolvimento de novas formas cognitivas para lidar com a crescente complexidade sistêmica da estrutura coletiva. Nesta nova escala da ordem social, o modelo centralizado e vertical dos líderes alfa se fragiliza, demandando a emergência de autorregulação do que se chama de sistemas complexos.

As mudanças sensório-cognitivas da ampla disseminação da comunicação mediada por computador é costumeiramente comparada às transformações no sistema perceptivo desencadeadas pelo processo de formação das metrópoles. Autores como Georg Simmel (1987), Walter Benjamin (1994) e Ben Singer (2004) mostram como o sistema perceptivo humano precisou se adaptar ao aumento da intensidade e frequência das ondas de hiperestimulação sensorial provocado pela nova configuração urbana. Analogamente, no

\footnotetext{
${ }^{2}$ Para uma descrição detalhada da interação entre as formigas ver Oliveira (2003).
} 
ambiente digital, o usuário é exigido em uma "percepção seletiva acurada para explorar, pinçar e conectar os conteúdos de interesse no meio do excesso e da fragmentação" (Regis et al, apud Regis e Messias, 2012, p. 43). A cultura digital submete o usuário a uma sobrecarga de estímulos sensoriais, exigindo reajustamento cognitivo na lida com o novo ambiente.

Uma reconceituação das noções de todo e de parte ajuda a entender o desgaste do paradigma hierárquico da comunicação top down, se consideramos fenômenos da comunicação em rede como sistemas complexos, ou seja, sistemas capazes de se autoafetarem e desencadearem modos de organização bottom up através de trilhas sígnicas, de modo a prescindir de líderes. Os enxames da internet têm algo a nos ensinar sobre a representação política? Os resultados do Google podem ser compreendidos como trilhas sígnicas humanas, de efeito similar aos rastros de feromônios das formigas. Os mecanismos de busca são tecnologias cognitivas que surgem em resposta ao volume crescente de dados. A metáfora das substâncias secretadas pelas formigas pode ser usada para entender a ampliação da rede informacional e o poder das tecnologias de rastreabilidade da atividade cognitiva dos usuários.

O poder da auto-organização digital está interferindo nas organizações com princípios hierárquicos bem definidos, como órgãos governamentais e partidos políticos. Moldados pelo formato comunicativo top down, deparam-se com um paradigma organizado de baixo para cima, resultado da inteligência viva e prática de multidões que se comunicam instantaneamente via tecnologias digitais móveis.

Muitos dirigentes de partidos políticos e autoridades conservadoras identificam o enfraquecimento de suas estruturas de vigilância e controle - bem como a origem de grande parte dos problemas de manutenção de prestígio e legitimidade - na expansão das redes distribuídas de comunicação digital (Amadeu, 2012, p. 283).

A ideia central a ser aproveitada é que tanto cidades, organizações coletivas de insetos sociais e softwares baseiam-se extensamente em feedback. Quanto mais interconectado um sistema, mas intenso é o fluxo de feedback em seu movimento de expansão e autorregulação, tornando-o menos dependente da tomada de decisões centralizada e de cima para baixo. 


\section{Ambientes cognitivos e a personalização midiática da política}

O tempo dedicado ao tema da política é reduzido nos meios de comunicação de massa. Na televisão aberta, ela normalmente aparece nos programas jornalísticos, além das inserções da propaganda eleitoral. Nos poucos minutos que recebe apresentamna sob a gramática do audiovisual e das fórmulas de exibição e narração do universo do entretenimento. A parte competitiva da política, isto é, da disputa entre personalidades, é aquela melhor assimilada ao mundo do espetáculo e que reúne condições de agregar às suas narrativas os ingredientes estéticos e dramáticos dos produtos ficcionais.

Já a face da política com menor probabilidade de ser selecionada pelos gatekeepers é a da disputa argumentativa, das sutilezas e complexidades discursivas específicas da administração pública e do jogo político regular e burocrático. Estas expressões mais abstratas da política, por assim dizer, costumam ter baixa seletividade no ambiente comunicacional de massa. Logo, as fórmulas do entretenimento midiático colocam o receptor em uma posição passivo-contemplativa (sem aqui duvidar da capacidade de discernimento e contextualização do espectador) diante do espetáculo político. No consumo de notícias, assistindo às manobras dos personagens do alto escalão da política em sua luta sem fim pelo controle estatal; na propaganda política, na desgastada fórmula de apresentação do político como um salvador, alguém em condições de resolver problemas complexos da sociedade com suas qualidades pessoais. Em ambos os casos, trata-se de uma lógica personalista: no jornalismo, focada nas agendas das celebridades políticas, transcrevendo suas declarações, especulando sobre os próximos passos e o reflexo que terão no quadro geral do jogo; na propaganda, presente na dimensão mítica forçosamente invocada pelo marketing para vender seus candidatos no mercado eleitoral.

Paulo Roberto Figueira Leal (2002) chama este cenário de "nova ambiência eleitoral”, em que há: crescente valorização do candidato, desvalorização da identificação partidária e prevalência de valores de curto prazo como instrumentos de decisão de voto. Com as novas possibilidades representadas pelo ciberespaço, essa ambiência - que não é mais tão nova - vem sendo mais uma vez abalada, já que a sociedade passa a questionar os personagens típicos e o modelo padrão de propaganda eleitoral. Ainda assim, o novo cenário não se alterou suficientemente para modificar essas três características observadas por Figueira Leal.

Mas nossa hipótese é de que esta lógica personalista pode estar se tornando incompatível com o padrão cognitivo emergente pelo uso massivo da internet. As propriedades das TIC como mediadoras das 
trocas humanas possuem um aspecto que altera profundamente os mecanismos de gestão das trocas:

\begin{abstract}
A era das tecnologias digitais criou uma etapa suplementar ao possibilitar às redes humanas a troca de informação e, posteriormente, integrando a essas redes dispositivos interativos que permitem rastrear as reações aos conteúdos em circulação, controlando e mapeando essas interações (Boutang, 2012, p. 80).
\end{abstract}

As tecnologias de rastreabilidade da atividade cognitiva mensuram a economia política dos afetos que emerge na internet. Todos os rastros ficam registrados e armazenados em bancos de dados no ciberespaço. As redes sociais tornam-se laboratórios censitários em tempo real (Ortiz, 2012, p. 333). Vimos aqui como estes traços ou rastros deixados pelas trocas e relacionamentos na rede são capturados e aproveitados pelo capital. Muito se tem comentado sobre a potência corruptiva dos sistemas cibernéticos, com os recentes escândalos de espionagem envolvendo os governos brasileiro e norte-americano.

Contudo, não podemos negar o potencial de transparência, diálogo e participação das TIC. A criação e manutenção de bancos de dados que permitem perspectivas inovadoras para a ação dos indivíduos na cena pública é um exemplo. As plataformas digitais de comunicação, em sua capacidade de armazenar, organizar e compartilhar informações de interesse público, podem contribuir para o aumento da transparência dos processos financeiro-administrativos no âmbito do Estado, assim como estabelecer grau mais elevado de responsividade, isto é, de resposta aos questionamentos e demandas dos cidadãos, aumentando $\mathrm{o}$ diálogo entre representantes $\mathrm{e}$ representados.

As TIC possibilitam que um modelo participativo e mesmo deliberativo se estabeleça como padrão cognitivo para lidar com a informação política. Esta nova constituição da noosfera pode ser hostil ao contrato comunicacional do ambiente imagético da mídia de massa, um contrato de "identificação projetiva", uma comunicação midiatizada que mais afasta do que aproxima o cidadão da política. O contrato da comunicação política nas linguagens da mídia massiva estabelece que o leitor/ouvinte/telespectador assista ao teatro das celebridades políticas como assistiria a uma narrativa ficcional.

Será que a cognição estimulada pelas TIC pode operar no sentido de diluir a concentração do personalismo, por conta do desenvolvimento de uma comunicação bottom up, que expresse mais afirmativamente sentido de coletividade, e apresente questões 
substanciais sobre os problemas e necessidades da coletividade? É claro que a mensuração ininterrupta da atividade cognitiva, que pode funcionar como medidor de popularidade em tempo real, tem sua crueldade e merece críticas. Mas não podemos abandonar a perspectiva de sua potência auto-organizadora, que possibilita um novo espaço para o desenvolvimento da meritocracia. Vejamos um exemplo simples. Um deputado eleito em uma metrópole não tem meios para se comunicar com a massa de eleitores que representa, com a qual se comunica de forma vaga e superficial, enfatizando sua imagem e principais realizações. A cognição se constrói no modelo de uma comunicação concentrada na personalidade do político.

Nos sistemas emergentes das TIC, elites e grande mídia perdem parte do poder de estabelecer os enquadramentos dominantes para as questões políticas, e outras instâncias podem adquirir relevância nos sistemas de circulação da informação, configurando um cenário em que a crescente fluidez da agenda política contribui para tornar aguda a crise da representação.

A atuação parlamentar, por exemplo, poderia estar permanentemente em vigilância na rede, com relatórios fornecendo cruzamento de informações sobre seu mandato, relativas ao seu posicionamento nas diversas questões de interesse do eleitor. Não é mais um contrato de comunicação em que o eleitor assiste "passivo" ao enredo preparado pelo marqueteiro ou pela assessoria do político, mas um ambiente ativo de informação. As plataformas de comunicação on-line têm notável potencial de organização, armazenamento e disseminação de informações para amplas audiências, de modo a contribuir para o aumento contínuo na transparência do Estado e nas ações de seus agentes e proporcionar relação mais dialógica, responsiva e inclusiva.

Neste ambiente emergente de mídia que estamos hipoteticamente imaginando, simplificações personalistas seriam gradualmente substituídas por relatórios de desempenho. A paisagem comunicacional esboçada por este novo paradigma está ainda muito distante da realidade. No entanto, acreditamos que transformações políticas mais amplas são antecedidas por uma reconfiguração do ambiente cognitivo, que pode ter tido nas recentes expressões de descontentamento com a representação política uma confirmação de já estar em andamento.

\section{Considerações finais}

A crise da representação é o ponto de partida para a construção de espaços de mediação e de interpretação das regras que permitem realizar concretamente projetos de vida social (Marazzi apud Malini, 
2009, p. 287). No capitalismo cognitivo das sociedades pósindustriais, a política vem sofrendo transformações com a expansão das redes de comunicação digital. Conforme exposto, a produção imaterial, afetiva e informacional escapa à medida do cálculo reducionista da economia industrial. Mas a estrutura das relações de poder ainda encontra fundamentos em uma lógica da disciplina e de um comando centralizado que impõe suas decisões em fluxo topdown.

As possibilidades proporcionadas pelas redes e mídias digitais reconfiguram o padrão sensório-cognitivo sobre o qual todos nós interpretamos a política que conhecemos preferencialmente através de linguagens semióticas. A influência das TIC nos processos de intermediação política pode fortalecer um modelo perceptivo que agudiza a dissonância cognitiva em relação às linguagens tradicionalmente produzidas pelos meios de comunicação. A crise nos modos de representação política neste ambiente cognitivo pode ser explicada, entre outras razões, pelo fato destas linguagens monológicas já não darem conta da realidade da comunicação instantânea em rede e da inteligência colaborativa que emerge dela.

As plataformas de gestão criativa desenvolvidas na internet permitem imaginar a ampliação da transparência e do acesso a bancos de informações de interesse público, "proporcionando a criação de espaços cada vez mais públicos e menos estatais" (Wu, 2012, p. 152). A instantaneidade e velocidade no processamento e na reprodução da informação - próprias do impacto da world wide web conjugado à telefonia móvel - redefinem a percepção de eficiência do Estado no atendimento às demandas da população, forçando a aceleração de uma reforma estrutural na governança da comunicação, através de uma "pressão de mercado".

Essa nova experiência sensitiva transforma as relações sociais e a própria política. A relação com a informação política on-line deve ser pensada a partir de uma abordagem multicausal baseada nas propriedades do novo ambiente comunicacional, assim como na mudança da condição de espectador para a de usuário. Como as novas modalidades sensoriais na relação dos usuários com as materialidades dos novos meios podem afetar a cognição política? A pesquisa em comunicação política deve buscar metodologias ajustadas à sofisticação das tecnologias da informação e comunicação para melhor compreender as reverberações destes meios nos processos cognitivos de formação de sentido para o mundo da política. A valorização de perspectivas interdisciplinares, como as das ciências cognitivas e neurociências, pode colaborar para dar início a esta frente de trabalho. 


\section{Referências}

BENJAMIN, Walter. "A obra de arte na era de sua reprodutibilidade técnica". In: Obras Escolhidas: magia e técnica, arte e política: ensaios sobre a literatura e a história da cultura. 7 ed. São Paulo: Brasiliense, 1994.

BOUTANG, Yann Moulier. Revolução 2.0, comum e polinização. In: Cocco, Giuseppe; ALBAGLI, Sarita (Org.). Revolução 2.0: e a crise do capitalismo global. Rio de Janeiro: Garamond, 2012.

HARDT, Michael; NEGRI, Antonio. Multidão: guerra e democracia na era do Império. Rio de Janeiro: Record, 2005.

JOHNSON, Steven. Emergência: a vida integrada de formigas, cérebros, cidades e softwares. Rio de Janeiro: Jorge Zahar Ed., 2003.

LEAL, Paulo Roberto Figueira. A nova ambiência eleitoral. Lumina, Juiz de Fora, v. 5, n. 2, p. 67-77, jul./dez. 2002.

MALINI, Fábio. A vida na produção just in time. Liinc em Revista, v. 5, n. 2, Rio de Janeiro, setembro 2009.

MENDES, Pedro. o que faz o Brasil, bRASIL? In: CocCO, Giuseppe; ALBAGLI, Sarita (Org.). Revolução 2.0: e a crise do capitalismo global. Rio de Janeiro: Garamond, 2012.

NEPOMUCENO, Carlos. Crise de representatividade: as redes sociais levarão a uma revolução cognitiva. Disponível em: http://cbn.globoradio.globo.com/cbn-rj/cbn-

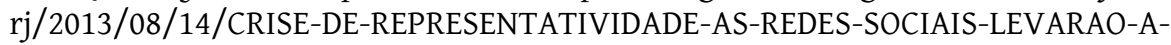
UMA-REVOLUCAO-COGNITIVA.htm. Acesso em 20/01/2014.

OLIVEIRA, Luiz Alberto. Biontes, Bióides e Borgues. In: NOVAES, Adauto (Org.). 0 homem-máquina: a ciência manipula o corpo. São Paulo: Companhia das Letras, 2003.

ORTIZ, Anderson. Enxame gera conhecimento? Sistemas emergentes, opinião pública e cognição. In: REGIS, Fátima; ORTIZ, Anderson; AFFONSO, Luiz Carlos; TIMPONI, Raquel. Tecnologias de comunicação e cognição. Porto Alegre: Editora Sulina, 2012.

PASQUINELLI, Matteo. O poder de abstração e o seu antagonismo. Sobre as psicopatologias do capitalismo cognitivo. Texto apresentado na conferência "Psychopathologies of cognitive capitalism". Berlim 7-9 de março de 2013.

PETTY, R. E.; CACIOPPO, J. T. Communication and persuasion: Central and peripheral routes to attitude change. New York: Springer-Verlag, 1986. 


\section{SANGIRARDI}

\section{compolítıca}

PRIOR, Markus. How media choice increases inequality in political involvement and polarizes elections. New York: Cambridge University Press, 2007.

REGIS, Fátima. Práticas de comunicação e desenvolvimento cognitivo na cibercultura. Intexto, v. 02, n. 25. Porto Alegre: UFRGS, 2011.

REGIS, Fátima; MESSIAS, José. Comunicação, tecnologia e cognição: rearticulando homem, mundo e pensamento. In: REGIS, Fátima; ORTIZ, Anderson; AFFONSO, Luiz Carlos; TIMPONI, Raquel. Tecnologias de comunicação e cognição. Porto Alegre: Editora Sulina, 2012.

SILVEIRA, Sergio Amadeu da. Redes cibernéticas e a reconfiguração da biopolítica. In: COCCO, Giuseppe; ALBAGLI, Sarita (Org.). Revolução 2.0: e a crise do capitalismo global. Rio de Janeiro: Garamond, 2012.

SIMMEL, Georg. "A metrópole e a vida mental". In: VELHO, Otávio (Org.).0 Fenômeno Urbano. Rio de Janeiro: Ed. Guanabara, 1987.

SINGER, Ben. "Modernidade, hiperestímulo e o início do sensacionalismo popular". In: CHARNEY, Leo \& SCHWARTZ, Vanessa (Orgs). o Cinema e a invenção da vida moderna. São Paulo: Cosac \& Naify, 2004.

WINKIN, Yves. A nova comunicação: da teoria ao trabalho de campo. São Paulo: Campinas, ed. Papirus, 1988.

WU, Vinicius. Cidadania e participação política no século XXI. In: COCCO, Giuseppe; ALBAGLI, Sarita (Org.). Revolução 2.0: e a crise do capitalismo global. Rio de Janeiro: Garamond, 2012.

COMPOITTICA ASSOEIACAO BRASILEIRA DE PESQUISADORES EM COMUNICACAOO E POLÍTICA

Presidente: Alessandra Aldé (UERJ)

Vice-Presidente: Luis Felipe Miguel (UnB)

Secretário Executivo: Francisco Jamil Marques (UFC)

Editora-Chefe:

Alessandra Aldé (UERJ)

Editores Executivos:

Edna Miola (UFS) e Viktor Chagas (UFF)

Editores Assistentes:

Eleonora Magalhães (UFF) e Fernanda Sanglard (UERJ)

Revisora: Fernanda Sanglard (UERJ)

<http://compolitica.org/revista>
A Revista Compolítica é uma revista eletrônica da Associação Brasileira de Pesquisadores em Comunicação e Política. Com periodicidade semestral, sua proposta é difundir a produção acadêmica relacionada às interfaces desses campos de estudo.

Ao citar este artigo, utilize a seguinte referência bibliográfica

SANGIRARDI, Pedro. Tecnologias cognitivas, comunicação e a crise de representação política. In: Revista Compolítica, n. 4, vol. 1, ed. janeiro-julho, ano 2014. Rio de Janeiro: Compolítica, 2014. 
